\title{
KONFLIK DAN RESOLUSI KONFLIK JAMA'AH MASJID KEMBAR MENARA TUNGGAL DI DESA BANYUMULEK KECAMATAN KEDIRI LOMBOK BARAT
}

\author{
AZWANDI \\ Dosen Fakultas Dakwah dan Ilmu Komunikasi UIN Mataram \\ Email: azwandi@uinmataram.ac.id
}

\begin{abstract}
Abstrak
Di desa Banyumulek terdapat dua masjid yang sekarang menjadi satu, masjid itu diberinama Masjid Kembar Menara Tunggal, sebelum masjid Kembar Menara Tunggal, sekitar enam puluh tahun yang lalu, berdiri salah satu masjid yang diberi nama Masjid Nurul Badiah, yang letaknya di Banyumulek Barat. Awalnya keberadaan masjid ini dimanfaatkan oleh warga Banyumulek sebagai tempat untuk beribadah dan sebagai pusat kegiatan keagamaan sebagaimana lazimnya. Namun Seiring berjalannya waktu, terjadi kesalahpahaman antar tokoh pemuka agama dan pengurus masjid itu. Sejak munculnya perbedaan pemahaman keagamaan ini, akhirnya konflik terbuka sesama jama'ah Masjid Nurul Badi'ah tidak dapat terelakkan, yang pada akhirnya jama'ah yang tidak sependapat mendirikan masjid baru yang lokasinya sangat berdekatan dengan Masjid Nurul Badi'ah, masjid baru tersebut diberi nama Masjid Silaturrahmi yang lokasinya berada di wilayah dusun Banyumulek Timur. Konflik dan ketegangan antar jama'ah terus berlangsung hingga puluhan tahun dan secara turun temurun, hingga pada akhirnya atas inisiatif dari tokoh pemuda pada saat itu, berusaha untuk menyatukan kembali jama'ah yang telah terpecah puluhan tersebut dengan melakukan negosiasi dan koordinasi dengan semua tokoh pemuka agama dan masyarakat, yang pada akhirnya menemukan titik temu untuk mengakhiri konflik yang berkepanjangan, dengan di adakan rapat besar antar dua pengurus masjid (Masjid Nurul Badiah dan Masjid Silaturrahmi) yang hasilnya di dalam rapat besar itu bahwa kepengrusan kedua masjid di bubarkan, dan kepengurusan masjid yang baru akan dibuat ulang, serta kedua masjid akan dirombak diganti dengan model masjid yang baru. Agar bangunan masjid bergabung menjadi satu maka dibuatkanlah jembatan penghubung yang sekarang dikenal dengan nama Menara Tunggal sebagai simbol pemersatu. Sejak dimulainya pembangunan Masjid Tunggal menara Tunggal dibangun pada tahun 2009 pertikain antar jamaah dapat diredam dan dapat dipersatukan kembali.
\end{abstract}

Kata Kunci : Konflik, Resolusi Konflik, Jam’ah Masjid

\section{Pendahuluan}

Masyarakat Indonesia dikenal sebagai masyarakat majemuk (pluralistik society). Hal tersebut dapat dilihat pada kenyataan sosial dan semboyan dalam lambang negara Republik Indonesia "Bhineka Tunggal Ika" (berbeda-beda namun satu jua). Kemajemukan masyarakat Indonesia ditandai oleh pelbagai perbedaan, baik horizontal maupun vertikal. Perbedaan horizontal meliputi kesatuan-kesatuan sosial berdasarkan suku bangsa, bahasa, adat istiadat, dan agama. Sedangkan perbedaan yang bersifat vertikal yakni menyangkut 
perbedaan-perbedaan lapisan atas dan bawah dalam masyarakat kita yang saat ini sangat tajam, baik di bidang sosial, ekonomi, politik maupun budaya. ${ }^{1}$

Keanekaragaman masyarakat Indonesia ini, di satu sisi merupakan berkah, karena keberagaman itu sesungguhnya merefleksikan kekayaan khazanah budaya. Tak heran jika Satjipto Raharjo sebagaimana dikutip Musahadi menyatakan bahwa Indonesia adalah laboratorium yang sangat lengkap dan menjanjikan untuk penelitian di bidang ilmu-ilmu sosial dan humaniora. Namun disisi lain, keberagaman juga berpotensi besar untuk tumbuh suburnya konflik, terutama jika keberagaman tersebut tidak mampu dikelola secara baik. ${ }^{2}$ Dan fakta menunjukkan bahwa konflik dan sengketa masih menjadi realitas sehari hari bangsa ini, mulai dari konflik politik, konflik ekonomi, konflik etnis, hingga konflik agama, konflik agama tidak saja terjadi antar agama yang berbeda atau yang dikenal dengan istilah konflik antar agama (inter-religious conflict) tetapi juga sering terjadi konflik antar umat dalam satu agama atau konflik intra agama (intra religious conflict).

Indonesia juga sebagai negara yang memiliki penduduk Islam terbanyak sedunia, tentu sebagai agama yang banyak dipeluk oleh penduduk Indonesia. Islam tentunya mempunyai peranan penting dalam perjalanan bangsa. Namun, Islam ternyata juga memiliki kemajemukannya sendiri, baik pada karakteristik ajaran, umat dan juga simbol keagamaan. Perbedaan pandangan dalam suatu agama bisa melahirkan konflik di dalam tubuh suatu agama. Perbedaan madzhab adalah suatu perbedaan yang nampak dan nyata. Kemudian lahir pula perbedaan ormas keagamaan. Walaupun satu aqidah yakni aqidah Islam, namun perbedaan sumber penafsiran dan penghayatan, kajian terhadap al-Qur'an dan al-Sunnah terbukti mampu mendisharmoniskan intern umat Islam. ${ }^{3}$

Aspek agama merupakan aspek yang sangat rentan dengan konflik. Karena sejarah agama-agama, atau mungkin tepatnya sejarah sosial berabad-abad menunjukkan bahwa

1 Said Agil Husin Al Munawar, Fikih Hubungan Antar Agama (Jakarta: Ciputat Press, 2003), hlm.viii

2 Musahadi HAM, Mediasi dan Resolusi Konflik di Indonesia: dari Konflik Agama Hingga Mediasi Peradilan (Semarang: Walisongo Mediation Center (WMC), 2007) hlm. vi. Sedangkan pendapat Syamsul Ma'arif dalam tulisannya Peace Building melaluui pendidikan Multikultural, sebagaimana dikutip Musahadi HAM dalam buku yang sama juga menyatakan: masyarakat Indonesia dengan tingkat kemajemukan sangat tinggi baik etnik, budaya, ras, bahasa, dan agama merupakan potensi sekaligus ancaman. Ibid, hlm. xix.

${ }^{3}$ M. Alfandi, Prasangka: Potensi Pemicu Konflik Internal Umat Islam, dalam jurnal Walisongo, Volume 21, nomor 1 mei 2013. hlm.114. 
struktur-struktur internal dari agama-agama tersebut (baik institusi ajaran, misi, kepemimpinan) telah melahirkan berbagai potensi konflik dan kekerasan. ${ }^{4}$

Konflik internal umat Islam juga pernah terjadi dan dialami oleh antar jamaah Masjid Kembar Menara Tunggal yang pada awal mulanya sekitar enam puluh tahun yang lalu, berdiri salah satu masjid yang diberi nama Masjid Nurul Badiah, letaknya di Banyumulek Barat. Awalnya keberadaan masjid ini dimanfaatkan oleh warga setempat untuk beribadah dan sebagai pusat kegiatan keagamaan. Seiring berjalannya waktu, ada kesalahpahaman antar tokoh agama dan masyarakat kala itu. Terkait masalah pelaksanaan ritual keagamaan di dalam masjid tersebut.

Berawal dari perbedaan pemahaman keagamaan ini, akhirnya konflik terbuka sesama jama'ah tidak dapat terelakkan walaupun tidak sampai pada benturan fisik. Karena sudah tidak ada titik temu untuk mendamaikan kedua belah pihak yang bertikai, akhirnya salah satu kubu memutuskan untuk membangun masjid baru, untuk menampung kelompok atau jama’ah yang berseberanga, dan pembangunan masjid baru terelaksanakan yang diberi nama Masjid Silaturrahmi, yang sekarang terletak di Banyumulek Timur. Pengaruh dari dibangunnya masjid baru (Masjid Silaturrahmi) Masyarakat setempat mulai terbelah dan berkotak-kotak. Karena rasa ego dari masing-masing kelompok dan bahkan sampai ke dalam lingkup keluarga. Dalam satu keluarga misalnya ada yang ikut jamaah Masjid Silaturrahmi, ada juga ikut jamaah Masjid Nurul Badiah.

Kondisi konflik dan ketegangan ini terus berlangsung dari tahun ke tahun, seakanakan tidak mungkin dipersatukan kembali terlebih masing-masing kelompok telah memiliki masjid sendiri. Sehingga persaingan antar kelompok semakin terlihat dan bahkan sampai hal pembangunan masjid juga, jika ada yang di rehab, di cat dan diperbaiki maka jama'ah masjid yang lain juga ikut melakukan hal yang sama.

Karena ketegangan dan konflik semakin kurang baik antar jama'ah, karena memang lokasi masjid yang asli dengan yang baru sangat berdekatan dan sangat mempengaruhi terhadap kelangsungan kegiatan ibadah, maka beberapa tokoh agama berupaya melakukan ishlah (rekonsiliasi) untuk mendamaikan kedua belah pihak yang bertikai, walaupun beberapa kali musyawarah antar pengurus tidak mendapatkan titik temu, pada akhirnya salah seorang tokoh menyampaikan niatannya ingin menjadi satu masjid sebagai pusat pembelajaran alias pondok pesantren. Kemudian satu lagi dijadikan sebagai masjid tempat

4 TH. Sumartana,"Pluralisme, Konflik dan Dialog;Refleksi tentang Hubungan Antaragama di Indonesia" dalam "Pluralisme, Konflik dan Pendidikan Agama di Indonesia”, editor TH. Sumartana, dkk (Yogyakarta: Institut?Dian Interfidei, 2010), hlm.79. 
beribadah. Kala itu, kedua pengurus setuju, namun kembali menjadi kendala tidak ada pengurus mau mengalah masjidnya dijadikan sebagai pusat pembelajaran agama.”Di situ tidak ada yang mau mengalah. Sehingga akhirnya di adakan rapat besar antar dua pengurus masjid yang hasilnya di dalam rapat besar itu Jamiludin mengambil inisiatif akan membangun menara besar di tengah masjid. Agar bangunan masjid bergabung maka dibuatkanlah jembatan penghubung yang sekarang dikenal dengan nama Menara Tunggal sebagai simbol pemersatu. Dibangun mulai tahun 2009 sehingga pertikain antar jamaah dapat diredam dan dapat dipersatukan kembali, pengurus masjidnya juga telah dilebur menjadi satu, masjid pun dijadikan satu dan diberi nama oleh masyarakat dengan Masjid Kembar Menara Tunggal.

Dari paparan singkat di atas, peneliti tertarik ingin mengetahui lebih jauh dan lebih jelas tentang bagaimana bentuk konflik yang terjadi, apa yang menyebabkan konflik bisa terjadi serta bagaimana proses perdamaiannya, sehingga konflik dapat diakhiri demgan penuh keharmonisan dan perdamaian sampai sekarang., dan perdamaian dapat tercpai tanpa ada pertumpahan darah sebagaimana yang terjadi di tempat-tempat lain.

\section{Kajian Penelitian Terdahulu}

Kajian pustaka ini dilakukan untuk melihat sejauh mana masalah ini pernah ditulis oleh orang lain dan menunjukkan bahwa penelitian yang dilakukan sekarang ini masih belum ada penelitian yang secara spesifik mengungkapkan tema yang dikaji peneliti. Namun demikian tulisan tentang konflik dan resolusi konflik jama'ah masjid bukanlah hal yang baru karena merupakan fenomena sosial yang telah banyak diteliti oleh para sarjana baik di tingkat nasional maupun internasional.

Diantara tulisan para sarjana yang membahas dan mengupas tentang managemen konflik dalam rumah tangga antara lain :

1. Shodiq Raharjo, Skripsi, dengan judul "Konflik antara NU dan Muhammadiyah (19602001); Studi kasus di Wookromo Pleret Yogyakarta), Fakultas Adab UIN Sunan kalijaga Yogyakarta, 2007. Dalam penelitiannya menjelaskan bahwa dengan adanya perbedaan interpretasi mengenai perangkat ajaran-ajaran agama Islam antara $\mathrm{Nu}$ dan Muhammadiyah telah menimbulkan konflik, mulai dari konflik kecil dalam kehidupan sehari kemudian merembet menjadi konflik besar yang mengarah kepada bentrok pisik.

\footnotetext{
5 Wawancara, Jamiluddin, Banyumulek, Tanggal, 10 Maret 2018
} 
Penyebab utama berawal dari masalah interpretasi ajaran agama meningkat menjadi masalah sosial politik.

2. Efi Asmi Suryani ${ }^{6}$, skripsi dengan judul “Resolusi Konflik Antara Pengusaha dan Pekerja di Pabrik Rokok; Studi Kasus Mengenai Demonstrasi Pekerja Akibat Pelanggaran Hak Normatif yang Dilakukan Oleh Pengusaha di Pabrik Rokok Adi Bungsu Kota Malang" Penelitian ini mengkaji resolusi konflik yang ditempuh oleh pekerja dan pengusaha serta menungkap hubungan industrial pasca resolusi konflik di pabrik rokok Adi Bungsu dan penelitian ini menggunakan teori konflik Relf Dahrendorf sebagai pisau analisis dalam mengupas konflik. Jenis penelitian yang gunakan yaitu penelitian kualitatif dengan pendekatan studi kasus.

3. Yurisa Irawan ${ }^{7}$, Skripsi dengan judul : Strategi Resolusi Konflik Organisasi Kerjasama Islam (OKI) dalam Konflik Thailand Selatan. Dalam penelitian ini peneliti menggunakan teori resolusi konflik model Hourglass, penelitian ini menyimpulkan bahwa strategi resolusi konflik yang dilakukan OKI di Thailand Selatan adalah: 1) conflict transformation, 2) conflict settlement, dan 3) conflict containment. Tujuannya adalah mencegah agar konflik kekerasan tidak terulang kembali (preventing violent conflict) baik itu mencegah secara mendalam (deep prevention) maupun secara ringan (lightprevention).

Dalam menjalankan conflict transformation, OKI merespons secara strategis konflik dengan cultural peacebuilding dan structural peacebuilding Respons strategis cultural peacebuilding dilakukan dengan misi pencarian fakta untuk mencari akar konflik dari tahun 2005. Dari hasil pencarian akar konflik, ternyata ditemukan permasalahan utama konflik Thailand Selatandisini adalah persoalan etnis yang kemudian meluas menjadi pelanggaran hak asasi manusia. Atas temuan ini OKI menyarankan kepada Pemerintah Thailand agar melakukan power-sharing secara kultural dengan mengakui keberadaan etnis Muslim Melayu dengan segenap budaya dan nilai-nilai mereka. Dengan begitu OKI bermaksud melakukan deep prevention.

Dalam menjalankan conflict settlement, OKI melakukan respons strategis peacemaking, Dengan mengirimkan duta khusus keThailand Selatan, membuka saluran

${ }^{6}$ Efi Asmi Suryani, "Resolusi Konflik Antara Pengusaha dan Pekerja di Pabrik Rokok; Studi Kasus Mengenai Demonstrasi Pekerja Akibat Pelanggaran Hak Normatif yang Dilakukan Oleh Pengusaha di Pabrik Rokok Adi Bungsu Kota Malang”, Skripsi, Jurusan Sosiologi, Fakultas Sosial dan Ilmu Politik, Universitas Brawijaya Malang, 2014.

7 Yurisa Irawan, Strategi Resolusi Konflik Organisasi Kerjasama Islam (OKI) dalam Konflik Thailand Selatan, Skripsi, Jurusan Ilmu Hubungan Internasional, Fakultas Ilmu Sosila dan Ilmu Politik, Universitas Andalas, Padang 2016. 
diplomasi,menjadi mediator Pemerintah Thailand dengan Kelompok Pemberontak, serta melakukan negosiasidengan kedua belah pihak. Tujuan OKI melakukan hal tersebut, jika dilihat dari resolusi konflik adalah untuk mencegah konflik kekerasan secara ringan (light prevention).

Pada conflict containment, OKI melakukan respons strategis peacekeepingdengan terus-menerus memonitor konflik yang terjadi dan berusaha untuk menahan gejolak yang terjadiantara masyarakat Muslim Thailand Selatan dengan pemerintah Thailandlewat resolusi yang dikeluarkan tahun 2010, 2013, dan 2015. Tujunnya adalah untuk mencegah konflik kekerasan secara ringan (light prevention).

Berdasarkan kajian pustaka di atas, menunjukkan bahwa penelitian tentang "Konflik Dan Resolusi Konflik Jama'ah Masjid Kembar Menara Tunggal di Desa Banyumulek Kecamatan Kediri Lombok Barat" belum ada yang melakukannya, jadi penelitian ini mempunyai spesifikasi tersendiri, serta ber tujuan untuk melengkapi dan melanjutkan penelitian terdahulu serta mencari jawaban atas permasalahan yang belum dipecahkan secara mendalam sehingga peristiwa di atas dapat diungkap, baik yang tersirat maupun yang tersurat.

\section{Gambaran Umum Desa Banyumulek}

Banyumulek adalah salah satu desa yang berada di kecamatan Kediri, Kabupaten Lombok Barat, Nusa Tenggara Barat, Indonesia. Bagi masysrakat Lombok Desa Banyumulek dikenal dengan sentra industri gerabah yang telah dikenal seantero pulau Lombok bahkan dikenal sampai maca negara sejak tahun 1990-an, yang di mana hampir seluruh penduduknya berkecimpung dalam pekerjaa pembuatan gerabah. Hingga saat ini Desa Banyumulek merupakan salah satu destinasi wisata di daerah Lombok. Selain dikenal dengan gerabahnya juga dikenal dengan masjid kembar menara tunggalnya walaupun sampai saat ini belum jadi sempurna seratus persen akan tetapi keindahan arsitektur masjid dan menara yang berada di tengah-tengah jalan ikut serta memperindah Desa Banyumulek.

Desa Banyumulek merupakan salah satu Desa yang berada di wilayah Kecamatan Kediri Kabupaten Lombok Barat. Jarak Banyumulek dengan Ibu Kota Provinsi (Mataram) sekitar $14 \mathrm{Km}$. Desa Banyumulek memiliki luas wilayah 243,43 $\mathrm{m}^{2}$ dengan batas wilayah sebagai berikut : Sebelah utara dari Desa Telaga waru Kec. Labuapi, Sebelah Seletan dari Desa Dasan Baru Kec. Kediri, Sebelah Timur dari Desa Lelede Kec. Kediri dan Sebelah Barat dari Desa Suka Makmur Kec. Gerung. Desa Banyumulek yang memiliki 
luas wilayah 243,43 $\mathrm{m}^{2}$ terbagi menjadi 10 dusun yakni : Dusun Pengodongan Indah, Karang Pande, Muhajirin, Mekar Sari, Dasan tawar, Gubuk Baru, Kerangkeng Barat, Kerangkeng Timur, Banyumulek Barat, Banyumulek Timur. Dengan total jumlah penduduk saat ini berjumlah 8092 dengan rincian laki-laki 3790 orang dan perempuan berjumlah 4320 orang.

Penduduk Banyumulek yang terbanyak adalah berada di Dusun Banyumulek Timur dengan jumlah penduduk laki-laki berjumlah 552 dan yang perempuan berjumlah 534 dengan jumlah total 1086, sedangkan Dusun Banyumulek Barat menempati urutan ke dua dengan jumlah penduduk seluruhnya 997 dengan ketentuan laki-laki berjumlah 489 dan perempuan 508. Dan yang menenmpati urutan ke tiga dari tingkat kepadatan penduduknya adalah Dusun Muhajirin dengan jumlah penduduk laki-laki 493 dan jumlah perempuan 496. Dan sebaliknya tingkat penduduk yang paling rendah adalah Dusun Pengodongan Indah dengan jumlah laki-laki berjumlah 228 dan jumlah perempuan 253 dengan total keseluruhannya adalah berjumlah 481. Sedangkan urutan ke dua adalah Dusun Kerangkeng Timur dengan jumlah laki-laki 313 dan jumlah perempuan 297, total jumlah keseluruhannya adalah 610. Dan yang menempati urutan ketiga dari jumlah penduduk terendah adalah Dusun Mekar Sari dengan jumlah penduduk 311 dan perempuan 305 total keseluruhannya adalah berjumlah 616. Sedangkan jika dilihat dari jumlah laki-laki dan perempuan yang ada di Desa Banyumulek, jumlah laki-laki terbanyak ada di Dusun Banyumulek Timur dengan jumlah laki-lakinya 552. Sedangkan yang paling banyak perempuannya adalah ada di Dusun Banyumulek Barat dengan jumlah perempuannya adalah 508.

Kondisi sosial budaya masyarakat Banyumulek, tidak jauh berbeda dengan kondisi masyarakat lain di sekitar wilayah Lombok Barat. Masyarakat Banyumulek masih tetap menjujung tinggi nilai-nilai lokalitas masyarakat seperti budaya gotong royong, budaya belangar, nyongkolan, acara selametan, nelung, mituk dan nyiwak, selamatan haji, selamatan kandungan (acara tujuh bulanan) dan budaya saling kunjung mengujungi (silaturrahim) antar sesama warga dan lainnya.

Penduduk masyarakat desa Banyumulek adalah seratus persen beragama Islam. Yang mayoritas adalah penduduk asli suku sasak. Dalam kehidupan sehari hari masyarakat Banyumulek menjalankan ibadah lima waktu di masjid, di mushalla dan di rumah tempat tinggal masing-masing.

\footnotetext{
8 Observasi tanggal 23 Juli 2018
} 
masyarakat Banyumulek, jika dilihat dari matapencahariannya adalah mayoritas berprofesi sebagai pengerajin industri rumah tangga, petani dan buruh tani, jumlah petani laki-laki mencapai 625 orang sedangkan perempuan berjumlah 18 orang, sementara jumlah buruh tani lebih banyak perempuannya mencapai 1000 orang sementara laki-laki sebanyak 50 orang. Sedangkan yang bergerak diprofesi pengerajin industri rumah tangga merupakan jumlah yang paling banyak mencapai 2600 orang, laki-laki berjumlah 2000 orang dan perempuannya 600 orang. Dari sini bisa kita ketahui bahwa masyarakat banyumulek memang mayoritas berprofesi sebagai pengerajin industri rumah tangga, bahkan hasil industri rumah tangga yang digelutinya berupa gerabah telah dikenal hingga mancanegara. Sedangkan matapencaharian masyarakat di profesi Polri dan TNI tergolong sangat minim, satu desa beru memiliki masing 1 orang.

Masyarakat Banyumulek rata-rata yang usia 18 -56 tahun tidak pernah sekolah dan tidak tamat SD, yang tidak pernah sekolah mencapai 771 orang laki-laki dan 1071 orang perempuan, sementara yang tidak sampai tamat SD, yang laki-laki berjumlah 591 orang dan yang perempuan berjumlah 631 orang. Sedangkan yang usia 7-18 tahun yang masih dalam proses pendidikan hingga saat ini berjumlah 796 orang laki-laki dan 883 orang perempuan. Sedangkan yang sudah lulus SLTP berjumlah 484 orang dengan rincian 220 orang laki-laki dan 264 orang perempuan. Yang lulus SLTA baru berjumlah 360 orang dengan rincian 170 orang laki-laki dan 190 orang perempuan. Sementara yang selesai sampai sarjana strata satu baru 19 orang dan seluruhnya wanita. Dan yang telah bisa mencapai sarjana strata dua baru berjumlah 3 orang.

\section{Gamabaran umum Masjid Kembar Menara Tunggal Desa Banyumulek}

Menurut H. Jamil, salah seorang tokoh dan ketua pengurus pembangunan Masjid Kembar menara tunggal, "bahwa Masjid Kembar menara tunggal ini merupakan dua masjid yang berbeda yang disatukan, sebelum menjadi satu menjadi masjid kembar menara tunggal, masjid pertama bernama Masjid Nurul Badiah yang pada saat itu posisinya berada di wilayah Banyumulek Barat dan yang kedua Masjid Silaturrahmi yang waktu itu masuk ke wilayah Banyumulek Timur, walaupun berbeda berbeda wilayah akan tetapi lokasi kedua masjid ini sangat berdekatan hanya di batasi oleh jalan umum. Menurut H. Jamil dalam keterangannnya juga bahwa masjid yang pertama dibangun di desa Banyumulek pada saat itu adalah masjid Nurul Badiah, Masjid Nurul Badi'ah berdiri atau dibangun sekitar tahun 1900-an, mengenai tanggal bulan termasuk juga siapa tokoh yang berinisiatif pertama untuk 
membangun masjid ini tidak ada yang tahu persis, para orang tua sekarang hanya tahu bahwa masjid itu sudah berdiri sejak nenek moyangnya, yang ia ingat masjid itu berdiri pada waktu itu hanya menggunakan kayu dan menggunakan dinding agar saja, besar atau luasnya masjid Nurul Badiah pada sat itu ukurannya sangat kecil berbentuk seperti mushalla tidak seperti yang dilihat sekarang ini tuturnya.

Masjid Nurul Badi'ah hingga saat ini telah mengalami perubahan dan telah direnovasi besar sampai empat kali perubahan dan pergantian beberapa generasi pengurus masjid.

Seiring dengan berkembangnya jama'ah masjid Nurul Badi'ah pada saat itu, dan menurut sebagian pendapat warga bahwa pengurus dan para tokoh masjid Nurul Badi'ah pada saat itu belum mampu memaksimalkan syiar Islam di masjid tersebut terlebih pada sat itu ada sebagian yang warga masyarakat yang masih menganut waktu telu sehingga terkadang masjid juga tidak dipakai untuk shalat lima waktu, hanya waktu-waktu tertentu saja, selain itu juga karena pada waktu itu hampir seluruh masyarakat Banyumulek bekerja sebagai petani, kebiasaan petani pada saat itu pergi pagi pulang menjelang malam sehingga masjid di pakai untuk shalat lima waktu pada saat itu hanya waktu subuh, maghrib dan isya'. Akhirnya sekitar tahun 1930-an inisiatif sebagian warga yang ingin menjalankan ibadah shalat lima waktu di masid dan tidak mau mengikuti apa yang dilakukan oleh para tokoh masjid Nurul Badi'ah yang tidak bisa menjalankan lima waktu untuk shalat jama'ah di masjid, berupaya untuk mendirikan masjid lagi untuk menampung aspirasi yang berseberangan pendapat dengan par tokoh Masjid Nurul Badi’ah, sehingga berdirilah Masjid Silaturrahmi yang waktu itu dibangun cukup sederhana, yang lokasinya sangat berdekatan dengan masjid Nurul Badi'ah.

Sejak berdirinya Masjid Silaturrahmi di dekat masjid Nurul Badi’ah, konflik antar jama'ah dan para tokoh mulai terlihat dengan jelas, jika salah satu masjid melakukan mengecatan atau pemugaran maka masjid yang lainnya juga ikut begitu juga dalam hal yang lainnya hingga terkesan saling bersaing. Persaingan yang kurang baik ini telah diwariskan ke anak keturunannya sampai H. Jamil merasakan hal itu, akuinya.

Akhirnya untuk menyudahi persaingan yang tidak sehat antar kedua jama'ah masjid tersebut atas inisiatif beberapa tokoh pemuda dan remaja melakukan negosiasi kepada kedua tokoh masjid tersebut untuk melakukan ishlah atau perdamaian dengan mendamaiakan antar jama'ah dan menyatukan masjid sebagai simbul telah berakhirnya persaiangan antar Jam’ah. 
Inisitif para pemuda ini di amini oleh kedua tokoh masjid tersebut dan mendapatkan dukungan cukup baik karena sudah mulai menyadari apa yang lakukan oleh para orantua terdahulu adalah kurang baik. Sehingga muncullah kata-kata dan pesan moral dari H. Rafi'i salah seorang tokoh agama Banyumulek saat itu yang mengatakan : “ dendek mbae temu temeh sak laek-laek” (artinya jangan sekali kali engkau temui maslah-masalah yang lalu itu) yang memberikan semangat kepada para pemuda yang menginisiasi persatuan para kedua tokoh masjid tersebut. Akhirnya dilakukan dua kali musyawarah besar tepatnya pada bulan mei tahun 2002 dengan menghadirkan kedua tokoh masing-masing, ${ }^{9}$ baik dari remaja, tokoh agama, dan tokoh masyarakat untuk melakukan urun rembug mengenai langkah selanjutnya dalam mengentaskan persaiangan antar jama'ah.

Beberapa keputusan yang bisa diambil pada saat itu adalah :

1. Dibuarkannya kedua Pengurus masjid yyang lama

2. Untuk pelaksanaan sholat lima waktu dan shalat jum'at dilaksanakan di satu masjid saja dan digilir setiap dua tahun sekali.

3. Membentuk pengurus takmir masjid yang baru yang diambil dari masingmasing tokoh pengurus masjid dari keduanya.

4. Kedua masjid dirombak dan diganti dengan bangunan masjid yang baru, selaku arsitektur yang ditunjuk untuk menggabar model bangunan masjid adalah Abdul Halim..

5. Sebagai simbul untuk mempersatuakan masjid dan menghilangkan perasaan masih masjid yang lama antar jama’ah maka nama masjid keda belah pihak di ganti dengan nama Masjid Kembar Menara Tunggal. Dan untuk menyatukan bangunan fisik kedua belah masjid yang sangat berdekatan maka kesepakatan musyawarah didirikan menara sebagai penghubung antar masjid. ${ }^{10}$

6. Biaya pembangunan kedua masjid di bebankan pada kedua jama’ah dengan dibentuk pengurus pembangunan masjid yang anggotanya diambil dari masing-masing pengurus masjid. ${ }^{11}$

9 Nama-nama tokoh yang di undang dari pengurus masjid nurul badi'ah antara lain : H.M. Syafruddin, H. Suhaimi, H. Islam, F. Rofi', H. Maksun Tolib. Sedangkan dari tokoh masjid silaturrahmi antara lain : H. Syukron Ismail, H. Arifin, Abhar, A. Jamil. Hasil wawancara dengan H. Jamil tanggal 27 Juli 2018.

10 Wawancara dengan H. Jamil, banyumulek Tangggal 27 Juli 2018

11 Pengurus masjid di bagi rata, jika ketua dari masjid nurul badi'ah maka wakilnya dari masjid silaturrahmi, demikian juga dengan sekretaris, bendahara dan anggota-anggotanya, hasil wawancara dengan 


\section{Bentuk-Bentuk Konflik Yang Terjadi Antar Jama'ah Masjid Menara Tunggal Di Desa Banyumulek}

Sebagaimana disampaikan Alo Liliweri, ${ }^{12}$ dalam bukunya yang berjudul "Prasanggka dan Konflik; Komonikasi Lintas Budaya Masyarakat Multikultural”bahwa konflik itu adalah suatu yang normal dan tidak dapat dielakkan sepanjang ada interaksi dan kerjasama antar manusia. Konflik mempunyai berbagai bentuk misalnya konflik antar pribadi, antar kelompok, konflik antar organisasi dan lain sebagainya. Konflik pada dasarnya memiliki beberapa unsur yaitu ada dua pihak yang terlibat, ada tujuan yang dijadikan sasaran, ada tindakan dan ada situasi yang melahirkan sebuah pertentangan.

Maka dari itu masyarakat dan konflik merupakan satu kesatuan yang tidak terpisahkan dan bersifat alamiah. Konflik timbul dari adanya perbedaan, perbedaan merupakan sifat hakiki dari kemanusiaan, dan oleh sebab itu manusia disebut dengan makhluk konfliktis (homo conflictus) yaitu makhluk yang selalu terlibat dalam perbedaan, pertentangan, dan persaingan baik suka rela maupun terpaksa. ${ }^{13}$

Barangkali demikian pula halnya dengan masyarakat Banyumulek, masyarakat banyumulek yang memiliki karakter dan sifat yang berbeda-beda antara satu dengan yang lainnya, maka tak heran jika terdapat beberapa bentuk konflik yang berkembang di antara jama’ah. Masjid Kembar Menara Tunggal.

\section{a. Bentuk-bentuk konflik}

Dalam kehidupan manusia bahkan di seluruh makhluk hidup tidak dipungkiri bahwa konflik selalu ada dan muncul dalam kehidupan masyarakat baik konflik antrpribadi, antar kelompok bahkan antar bangsa di dunia sebagai bagian dari peradaban manusia. Disadari atau tidak, konflik merupakan budaya manusia sekaligus konsekuensi dari interaksi sosial. Untuk itu, Konflik dan termasuk juga kekerasan merupakan dua hal yang tidak pernah kosong dari kehidupan manusia, selama masih ada suatu perbedaan atau salah paham maka konflik dan kekerasan ini tidak dapat dihindarkan dalam kehidupan manusia atau dalam tiap kelompok manusia.

12 Alo Liliweri, "Prasanggka dan Konflik; Komonikasi Lintas Budaya Masyarakat Multikultural" (Yogyakarta : PT. LkiS Printing Cemerlang, 2005), h. 261.

${ }^{13}$ Novri Susan, "Pengantar Sosiologi Konflik dan Isu-Isu Konflik Kontemporer" (Jakarta: Kencana Prenada Media Group, 2009), h. 8 
Menurut Robby I Chandra ${ }^{14}$ yang mengutip pendapat Wehr, mengungkapkan bahwa konflik adalah suatu konsekuensi dari komonikasi yang buruk, salah pengertian, salah perhitungan, dan proses-proses lain yang tidak kita sadari. Untuk tidak salah jika dikatakan bahwa manusia disebut dengan makhluk konfliktis (homo conflictus) yaitu makhluk yang selalu terlibat dalam perbedaan, pertentangan, dan persaingan baik suka rela maupun terpaksa. ${ }^{15}$

Konflik antara jama’ah di Banyumulek, setidak-tidaknya dapat di kelompokkan menjadi beberapa bentuk konflik antara lain :

\section{Konflik internal pengurus masjid}

Konflik internal pengurus masjid tidak jarang terjadi di masyarakat, hal ini biasanya disebabkan oleh beberapa faktor diantaranya adanya ketidak sejalanan pola pikir, gaya kepemimpinan, sifat dan karakter pengurus yang berbeda-beda dan adanya kesalah pahaman dianatara pengurus dalam menyikapi sesuatu hal. Barangkali sama juga apa yang dialami oleh para pengurus Masjid Nurul Badi'ah (sebelum menjadi masjid kembar menara tunggal), H. Jamiluddin menjelaskan kronologi sebab-sebab mengapa jama'ah masjid Nurul Badi’ah membangun masjid baru yang tempatnya juga sangat berdekatan dengan masjid nurul badi’ah, yakni yang diberi nama masjid silaturrahmi.

Dalam penjelasannnya $\mathrm{H}$, Jamiludin mengungkapkan bahwa pada awalnya para pengurus masjid Nurul Badi'ah berselisih paham tentang pola pemakmuran masjid, karena pada saat itu masih terdapat islam waktu telu sehingga pemanfaatan masjid sebagai tempat ibadah tidak maksimal sehingga oleh sebagian pengurus masjid yang lain serta diikuti oleh jama'ah yang lain, akhirnya pengurus dan jama'ah masjid Nurul Badiah terpecah menjadi dua kelompok, satu kelompok ingin tetap melaksanakan ibadah di masjid nurul badiah, sementara yang lain ingin berhenti menjadi jama'ah Masjid Nurul Badi’ah dan berkeinginan mendirikan masjid baru, akhirnya pembangunan masjid baru yang diberi nama masjid silaturrahmi berdiri dan tepat di dekat masjid nurul badi'ah. ${ }^{16}$

Dari penjelasan H. Jamiludin ini, dapat kita pahami bahwa keberadaan masjid silaturrahmi bukanlah didirikan atas dasar banyaknya jama'ah atau karena

14 Robby I. Chandara, “Konflik dalam Kehidupan Sehari-hari”,(Yogyakarta:Kanisius,1992), hlm. 17

\footnotetext{
15 Novri Susan, "Pengantar sosiologi Konflik....hlm. 8.
}

16 Wawancara, H. Jamiludin, Banyumulek, Tanggal 30 Juli 2018. 
ketidak ketertapungannya jama'ah Masjid Nurul Badi'ah, akan tetapi karena adanya perselisihan pemahaman antar pengurus masjid, yang berimbas kepada anggota jama'ahnya sehingga terpecah menjadi dua kubu, ada yang berkeinginan untuk tetap sebagai jama'ah masjid nurul badi'ah dan ada yang berhenti dan membuat masjid baru yang pada saat itu Masjid Baru itu diberinama Masjid Silaturrahmi yang posisinya berada di wilayah Dusun Banyumulek Timur. Sehingga setelah dibangunnnya masjid silaturrahmi ini jama'ah masjid yang pro untuk pindah, maka jama'ah pindah tempat melaksanakan ibadah shalat dan lainnya, walaupun jarak dari tempat tinggalnya lebih dekat dengan masjid nurul badi’ah, tapi karena pro kepada yang pindah maka jama'ah juga sungkan untuk tetap di masjid nurul badi'ah. Demikian pula sebaliknya bagi jama'ah yang yang tidak ingin pindah dari masjid nurul badi'ah walaupun tempatnya lebih dekat dengan masjid silaturrahmi, jama'ah masjid nurul badi'ah tatap melaksanakan ibadah shalatnya di masjid nurul badi’ah.

\section{Konflik internal keluarga}

Imbas dari konflik di masjid Nurul Badi’ah, terbawa juga ke konflik keluarga, pada beberapa keluarga walupun tempat tinggal sama dan masih satu keluarga, tapi karena yang bersangkutan itu mendukung salah satu kubu dalam konflik pengurus masjid itu, maka dikian pula yang terjadi pada internal keluarga, ada sebagian ke masjid nurul badiah ada juga sebagian ke masjid silaturrahmi.

Dalam hal menyangkut kegiatan-kegiatan keagamaan, seperti perayaan nuzulul qur'an, peringatan maulid Nabi Saw. dan lainnya di internal keluarga juga ikut terpecah tergantung masjid mana yang diikuti, walaupun demikian konflik di internal keluarga masih tetap terjaga kekeluargaannya walaupun berbeda pandangan dalam menyikapi konflik. ${ }^{17}$

\section{Konflik kepentingan}

Memang jika dilihat kasat mata yang terlihat adalah konflik antar pengurus masjid, akan tetapi jika ditelusuri lebih dalam memang ada sebagian jama'ah nurul badi'ah (masih bersatu) pada waktu itu yang memilki kepentingan ingin kepengurusan masjid nurul badi'ah agar tidak dikelola oleh satu keluarga terlebih yang menjadi pengurus dianggap belum mampu menjadi tokoh panutan dan belum mampu memakmurkan masjid secara maksimal. Sehingga kalau tetap beraada menjadi jama’ah masjid nurul badi'ah maka akan tetap apa adanya seperti mereka.

17 Wawancara, H. Fathurrahman, Banyumulek, tanggal 30 Juli 2018. 
Sehingga bagaimana agar bisa berubah agar fungsi masjid dapat dilestarikan dan dimakmurkan, maka jalan keluarnya adalah dengan berani keluar dari jama'ah masjid nurul badi'ah dan membangun masjid lebih baik dari masjid nurul badiah. Maka terlaksanalah apa yang menjadi motip keinginannya sehingga berdirilah masjid silaturrahmi.

\section{Konflik kekuasaan}

Manusia yang dikenal sebagai Homo Homini Socius memiliki kebutuhan dan keinginan untuk berkumpul serta berinteraksi dengan sesamanya. Dalam tataran formal, aktifitas berkumpul dan berinteraksi ini dapat disebut dengan berorganisasi. Hal ini sejalan dengan buah pikiran Mc. Shane dan Von Glnow yang mengemukakan bahwa "Organizations are groups of people who work interdependently toward some purposes... Throughout history, organizations have consisted of people who communicate, coordinate, and collaborate with each other to achieve common objectives". Dalam organisasi, individu-individu yang unik berkumpul, berkolaborasi, dan berkoordinasi untuk mencapai tujuan tertentu. Keunikan individu yang beragam inilah yang kemudian memunculkan hal-hal penting di dalam organisasi, seperti kekuasaan, politik, dan konflik. ${ }^{18}$ Kekuasaan adalah kapasitas seseorang, tim, atau organisasi untuk mempengaruhi yang lain. Kekuasaan tidak dimaksudkan untuk mengubah perilaku seseorang, melainkan potensi untuk mengubah seseorang. ${ }^{19}$

Bentuk konflik selanjutnya adalah konflik kekuasaan, konflik kekuasaan sebagaimana di jelaskan di atas bahwa kekuasaan adalah kapasistas seseorang untuk mempengaruhi orang lain, kekuasaan yang diperoleh jama'ah Nurul badi'ah pada waktu itu bisa saja tidak memperoleh apa-apa karena kekuasaan tertinggi ada pada kelompok yang lain, maka latar belakang itulah bagaimana agar bisa menjadi penguasa bukan menjadi orang yang dikuasai tetapi bagaimana bisa menjadi penguasa, untuk memperoleh kekuasaan itu, maka harus berani keluar dari tirani kekuasaan itu. Yang pada akhirnya mampu mendirikan masjid baru yang dengan masjid barunya lebih leluasa dalam pengelolaannnya. Hal ini sebagaimana

\footnotetext{
${ }^{18}$ Nani Fitriani, Kekuasaan, Politik, dan Konflik di dalam organisasi akses tanggal 25 oktober 2018.

${ }^{19}$ Mc Shane, S.L. \& Von Glnow, M.A.Y. Organizational Behavior: Emerging Knowledge and Practice for the Real Word. (New York: Mc Graw Hill. 2010), Hlm.300.
} 
disampaikan oleh Khairul Waritsin : "memang pada saat itu yang menjadi pengurus adalah kebanyakan dari keluarga dekatnya, hampir tidak ada orang lain” ${ }^{20}$ sehingga wajar jika jama'ah lain yang tidak sepaham dengannya ingin mendirikan masjid baru.

\section{Konflik Latent (tersembunyi) dan manifes (terbuka)}

Konflik yang terjadi antar jamaah masjid Nurul badi’ah dengan jama'ah masjid Silaturrahmi, tergolong dalam tataran konflik latent (tertutup) dan konflik manifes (terbuka). Konflik latentnya bisa dilihat dari anatara lain:

1). Adanya perbedaan pandangan dan pendapat antar sesama jama'ah, yang pada awalnya tidak disampaikan dengan terang-terangan.

2). Bentuk perbedaan pendapat mulai diekspresikan dalam bentuk perilaku dan sikap sehari-hari yang pada akhirnya mulai memberanikan diri untuk melakukan konfrontasi dan perlawanan

3). Komunikasi antar sesama jama'ah mulai terganggu dan silaturrahmi menjadi tertutup. Selanjutnya meningkat ke konflik dipermukaan; seperti mau memberanikan diri untuk melawan dengan cara mendirikan masjid lain, sikap dan perilaku mulai lebih tampak, mana jama'ah Nurul Badi’ah dan mana jama'ah Masjid Silaturrahmi kian tampak, persaingan antar jama'ah semakin nampak, keretakan antar enggota keluarga semakin besar karena ada yang pro dan kontra.

Sedangkan konflik manifesnya dapat dilihat dari sisi sikap dan prilakunya dengan orang lain yang tidak sepaham dengannnya dan dapat juga dilihat dari didirikannya masjid baru masjid silaturrahmi yang merupakan imbas dari perseturuannya dengan kelompok lain.

\section{b. Faktor Penyebab Konflik}

Konflik yang terjadi pada manusia berasal dari berbagai macam faktor penyebab. Begitu beragamnya faktor penyebab terjadinya konflik antar manusia, sehingga sulit untuk dideskripsikan secara jelas mengenai sumber dari konflik itu. Hal ini dikarenakan sesuatu yang seharusnya bisa menjadi sumber konflik, tetapi pada kelompok manusia tertentu ternyata tidak menjadi sumber konflik, demikian halnya sebaliknya. Kadang sesuatu yang sifatnya sepele bisa juga menjadi sumber konflik antara manusia. Kesimpulannya sumber konflik itu sangat beragam dan

20 Wawancara, Khairul waritsin, 29 Juli 2018. 
kadang sifatnya tidak rasional. Oleh karena tidak bisa menetapkan secara tegas bahwa yang menjadi sumber konflik adalah sesuatu hal tertentu, apalagi hanya didasarkan pada hal-hal yang sifatnya rasional. Namun pada umumnya konflik diakibatkan oleh adanya perbedan-perbedaan, baik itu dalam pandangan, pendapat, ucapan, perbuatan, budaya, adat dan lain sebagainya. ${ }^{21}$

Jika dirunut secara lebih mendalam, bahwa konflik yang terjadi di Banyumulek antar jama'ah Masjid Kembar Menara Tunggal Banyumulek disebabkan atau bersumber dari beberapa faktor, antara lain:

\section{Adanya perbedaan pendapat dan pemahaman}

Yusuf Qardhawi ${ }^{22}$, mengemukakan bahwa persoalan perbedaan pendapat merupakan hal yang tak mungkin dihindari dan tak mungkin dapat dihentikan dengan tulisan-tulisan ilmiah atau seminar-seminar. Juga tak bisa dihentikan dengan diterbitkannya kitab-kitab sepanjang sebab-sebab perbedaan itu ada. Maka perbedaan itu tak akan pernah sirna. Bahkan dia beranggapan, religiusitas yang sangat dalam pada dada kaum muslimin, sering menimbulkan keteganganketegangan perbedaan yang sangat tidak toleran. Dimana tiap-tiap pihak dengan penuuh semangat mempertahankan pendapatnya masing-masing dan menganggapnya paling benar. Mereka menyangka, pendapat mereka adalah agama itu sendiri yang mungkin seseorang dengan mengikuti atau tidak mengikutinya bisa mendapat pahala atau dapat siksa. Mereka telah dengan sekuat tenaga, menjadikan pendapat-pendapatnya sebagai sesuatu yang sangat sakral dan sangat anti terhadap perbedaan. Sebuah sikap yang sebetulnya sangat tercela, karena akan terjadi pengedepan absolutisme pemikiran dan pendapat yang sangat menghambat nilai-nilai kemungkinan untuk berbeda yang dijamin Islam. Perbedaan pendapat akan selalu ada sepanjang nash-nash, yang dari sana diambil kesimpulan sebuah hukum, terbuka bagi sebuah penafsiran yang menghasikan kesimpulan yang berbeda. Dan sepanjang pemahaman setiap orang juga tidak berbeda dalam satu tataran dalam pengambilan kesimpulan, maka perbedaan ini akan terus berjalan.

21 William Chang, "Konflik komunal di Indonesia saat ini", (jakarta: Kerjasama INIS dan PBB UIN, 2003), hal. 27

22 Mustafa Malaikah, "Manhaj dakwah Yusuf Al-Qardhawi: Harmoni antara Kelembutan dan Ketegasan”, (Jakarta: Pustaka Al-Kautsar, 2001), hlm.x 
Perbedaan pendapat dikalangan jama'ah telah tampak sejak masih berada bersama-sama menjadi jama'ah di masjid Nurul Badi’ah. Perbedaan pendapat diantara para pemuka agama pada saat itu berimbas kepada para jama'ah, hal-hal yang membuat kesalah pemahaman pada saat itu, menurut H. Jamiludin dalam penjelasannya mengatakan :

“ bahwa pada saat itu agar masjid di jadikan tempat ibadah shalat setiap lima waktu, akan tetapi karena sebagian pengurus terutama yang memiliki kekuasaan atas masjid itu tidak bersedia menjalankan lima waktu, karena adanya kesibukan sehingga tidak bisa menjalankan shalat lima waktu di masjid tersebut, karena memang orang-orang dulu sawahnya luas dan jauhjauh sehingga kalau berangkat pagi maka pulangnya menjelang magrib, sehingga untuk shalat zhohor dan asharnya tidak bisa di laksanakan di masjid, sementara jama'ah yang lain yang tidak memiliki kesibukan yang sama ia menginginkan agar bisa melaksanakan shalat lima waktu itu di masjid, memang pada waktu itu juga ada sebagaian yang masih menganut islam waktu telu...dan maklum orang-orang dulu juga masih awam sekali masih jarang orang-orang yang pintar tidak seperti sekarang" ${ }^{23}$

Dari keterangan ini jelas bahwa awal ketegangan antar kelompok dimulai dari adanya perbedaan pemahaman dan pendapat antar jama'ah yang satu kelompok menginginkan tiga waktu sedangkan kelompok yang lain menginginkan lima waktu. Ketidak tersalurkannya aspirasi pendapatnya ini sehingga membuat masjid baru, dengan harapan agar bisa menjalankan ibadah shalat lima waktu di masjid dengan baik.

\section{Mis-Komunikasi antar para tokoh pemuka agama}

Mis-komunikasi yaitu kesalah pahaman komunikasi antara pemberi pesan dan penerima pesan. Mis-komunikasi ini bisa terjadi karena disebabkan beberapa faktor diantaranya adalah faktor pengetahuan dan bahasa. Artinya, orang-orang yang memiliki latar belakang pengetahuan, pengalaman, dan bahasa yang sama, akan lebih mudah mencapai kesamaan persepsi, demikian pula sebaliknya orang yang memiliki pengetahuan, pengalaman dan bahasa yang tidak sama maka akan tidak akan mudah menyamakan persepsi.

Mis-komunikasi antar kedua kelompok jama’ah disebabkan karena adanya perbedaan pendapat, komunikasi yang tidak sejalan, sejak adanya perbedaan pendapat sebagaimana dijelaskan di atas mengakibatkan mis-komunikasi antar jama'ah, karena kelompok yang satu beranggapan aspirasinya tidak bisa ditunaikan, sebagain kelompok yang lain menuding bahwa terlalu memaksakan kehendak, karena menginginkan sesuatu yang masih belum bisa dilaksanakan.

23 Wawancara, H. Jamiudin, Banyumulek, tanggal 30 juli 2018 


\section{Adanya anggapan akan kurang mampunya dalam mengelola masjid}

Pengelolaan masjid atau disebut juga dengan idaroh masjid atau manajemen masjid, pada garis besarnya dapat dibagi menjadi dua bagian yaitu : (1) manajemen pembinaan fisik (physical management) dan (2) pembinaan fungsi masjid (functional mmanagement) ${ }^{24}$ Berhasil dan gagalnya pengelolaan suatu masjid tentu sangat bergantunng pada kepengurusannya dan sistem dalam pengelolaan masjidnya.

Demikian pula halnya dengan konflik internal jama'ah masjid nurul badiah (dulu), sebagian jama'ah menganggap bahwa pada saat itu pengurusnya dianggap tidak mampu mengelola masjid dengan baik, masjid hanya di pakai untuk shalat itu pun tidak bisa dilakukan sampai lima waktu, hanya tiga waktu, oleh karena anggapan kekurang mampuan pengurus dalam hal mengelola dan memakmurkan masjid tidak baik, dan jika merubah pengurus juga tidak mungkin bisa karena yang ada di pengurusan adalah orang-orang yang cukup berpengaruh dan disegani pada saat itu, maka jalan keluarnya adalah hanya dengan mendirikan masjid baru. ${ }^{25}$

4. Adanya peran tokoh agama dan masyarakat yang ikut menggiring jama'ah sehingga memperkeruh dan memperbesar konflik.

Peran tokoh agama dan pemuka masyarakat terhadap jama'ah masjid Kembar Menara Tunggal mempunyai peran yang sangat penting dalam menggerakkan masyarakat/jama’ah. Himbauan dan sarannya dalam mempengaruhi warga masyarakat atau juga sangat ditentukan oleh cara tokoh agama dalam menggunakan kewenangan sebagai pemimpin agama.

Masing-masing kelompok jama'ah masjid nurul badi'ah dan masjid silaturrahmi memiliki tokoh panutan, yang pada awalanya tokoh-tokoh ini masih dalam satu jama'ah di masjid Nurul Badi'ah, karena beberapa tokoh ini perselisih paham dan terjadi mis komunikasi, maka masing-masing tokoh berusaha megiring para pengikutnya sesuai dengan keinganannya. Dan bahkan setlah masing-masing kelompok memiliki masjid sendiri perseteruan semakin tampak sampai-samapai jika masjid sebelah di cat maka masjid yang lain juga ikut mengecat, jika masjid sebelah melakukan renovasi, maka masjid sebelah juga ikut 
serta merenovasi. Para pemuka pengurus masjid ikut serta adil ambil bagian dalam memperkeruh konflik antar kelompok jama’ah, sebagaimana disampaikan oleh H. Jamiludin :

“pokoknya apa yang dilakukan oleh masjid nurul badi’ah, maka demikian pula yang dilakukan oleh jama’ah masjid silaturrahim, demikian pula sebaliknya. Jika masjid silaturrahim mengecat masjidnya, maka besoknya masjid Nurul Badi'ah ikut juga mengecat masjidnya, tentu ini tidak lepas dari peran para tokoh pemuka masjid yang ikut serta menggerakkan jama'ahnya, sehingga bisa berbuat demikian" ${ }^{6}$

Jadi sebagaimana paparan di atas bahwa bahwa paktor penyebab lahirnya konflik internal jama'ah masjid Nurul Badi’ah (dulu) adalah disebabkan juga oleh adanya peran tokoh pemuka masjid yang ikut serta menggiring jama'ahnya untuk mengikuti pendapatnya sehingga konflik internal jama’ah tidak dapat terelakkan.

\section{Resolusi Konflik Terhadap Konflik Jama'ah Masjid Kembar Menara Tunggal Di Desa Banyumulek}

\section{Mediasi}

Salah satu upaya resolusi konflik yang digunakan pada konflik antar jama’ah Masjid Kembar Menara Tunggal adalah dengan menggunakan mediasi konflik, yang mana keunggulannya mediasi konflik ini adalah menawarkan win-win solution dalam konflik yang dihadapi yang sama-sama menguntungkan kedua belah pihak.

Mediasi sebagaimana didefinisikan oleh Musahadi $\mathrm{HAM}^{27}$, adalah suatu proses dimana para pihak yang bersengketa menunjuk pihak ketiga yang netral untuk membantu mereka dalam mendiskusikan penyelesaian dan mencoba menggugah para pihak untuk menegosisasikan suatu penyelesaian dari sengketa itu. Tujuannya yang utama adalah tercapainya kompromi dalam menyelesaikan suatu persengketaan. Prosesnya bersifat pribadi, rahasia (tidak terekspos keluar) dan kooperatif. Selaku pihak keiga yang tidak memihak, mediator membantu para pihak (perorangan atau lembaga) yang bersengketa dalam menyelesaikan konflik dengan mendekatkan atau mempertemukan kepentingan-kepentingan yang berbeda dari para pihak.

Salah satu cara untuk mendamaikan kedua belah jama'ah (jama'ah masjid Nurul Badi'ah dengan jama'ah Masjid Silaturrahmi) yang telah terpecahkan sejak puluhan tahun yang silam adalah dengan cara mediasi. Cara mediasi merupakan cara

26 Wawancara, H. Jamiluddin, Banyumulek, tanggal 30 Juli 2018.

27 Musahadi HAM, "Mediasi dan Resolusi Konflik.., hlm.viii 
yang lebih tepat untuk mempersatukan keduabelah pihak. ${ }^{28}$ Yang menginiasi dan yang menjadi mediator pada saat itu adalah para tokoh pemuda dan remaja termasuk H. Jamiludin pada saat masih muda. H. Jamiludin besama tokoh-tokoh pemuda yang lain melakukan pendekatan kepada tokoh-tokoh masing-masing dan mengungkapkan niat dan mohon dukungannya agar bisa menyatukan kembali jama'ah yang telah lama terpecah.

Dukungan pun mengalir dari semua tokoh termasuk dari masing-masing tokoh dari kedua jama'ah, setelah mendapatkan dukungan dan doa restu dari semua unsur tokoh agama, masyarakat, pemuda dan remaja, baru membuat list nama-nma dari kedua belah pihak yang nantinya bisa diajak untuk musyawarah guna bersatunya kembali jama'ah yang telah terpecah. Setelah nama-nama tokoh di buat dan mentukan waktu dan tempat yang tepat untuk melakukan musayawarah. Serta setelah berkoordinasi dengan semua pihak termasuk semua pengurs masjid dari kedua belah pihak dan dari aparat pemerintah, maka berulah musyawarah dilaksanakan. ${ }^{29}$

\section{Dialog (Musyawarah)}

Dialog (musyawarah) merupakah salah satu cara untuk menyelesaikan konflik dan perbedaan antar jama’ah Masjid Kembar Menara Tunggal Banyumulek. Dialog adalah untuk membuka kesempatan mendengar penjelasan masing-masing pihak yang berkonflik. Untuk itu, tujuan dialog sebagaimana diungkapkan oleh St. Sunardi $i^{30}$ adalah bertujuan untuk penciptaan kerukunan, pembinaan toleransi dan kesejahtraan bersama, membudayakan keterbukaan, mengembangkan rasa saling menghormati, saling mengerti, membina integrasi, berkoeksistensi diantara penganut pelbagai agama dan sebagainya. Selain itu, dialog bisa mencapai tujuan yang lebih penting dari koeksistensi, yaitu pro-eksistensi. Dalam koeksistensi dialog hanya mengutamakan terciptanya toleransi sebagai satu-satunya tujuan. Proeksistensi lebih dari sekedar toleransi, yaitu selain mencari dan mengumpulakan segala persamaan doktriner, tradisi, semangat dan sejarah, juga berupaya mencari unsur-unsur yang meliputi perbedaan, bahkan yang menyimpan konflik pun harus di nyatakan.

Penyelesaian konflilk antar jama'ah masjid Nurul Badi’ah dengan jama’ah Masjid melui hasil musyawarah dan dialog antar pengurus dan jama’ah dari kedua

28 Wawancara H. Jamiludin, Banyumulek, Tanggal 30 Juli 2018.

29 Diolah dari hasil wawancara dengan H. Jamiludin, Banyumulek, Tanggal 30 Juli 2018.

30 St. Sunardi, "Dialog Cara baru Beragama; Sumbangan Hans Kung bagi Dialog Antaragama", dalam Abdurrahman Wahid,dkk, "Dialog: Kritik dan Identitas Agama”, (Yogyakarta: Dian/Interfidei, 1993), hlm.72. 
belah pihak dianggap berakhir, musyawara atau rapat itu disebut rapat akbar oleh $\mathrm{H}$. Jamiludin karena mempertemukan kedua pihak yang masih bertikai. ${ }^{31}$ Rapat akbar ini jatuh pada bulan mei tahun 2002 yang hasil musyawarah pada saat itu mengahasilkan, antara lain :

1. Semua kepengurusan masjid yang di kedua masjid dinyatakan dibubarkan.

2. Perseteruan antar jama'ah masjid dianggap sudah berakhir.

3. Kedua masjid (Masjid Nurul Badiah dan Masjid Silaturrahmi) akan dibongkar kedua-duanya, dan akan dibuat sama.

4. Panitia pembangunan masjid diambil dari masing-masing kelompok jama'ah.

5. Perubahan nama masjid (nama masjid tidak lagi menggunakan nama masjid yang lama), sebagai simbul telah bersatunya kembali para jama’ah.

6. Masjid yang telah dibongkar akan dibuat baru dan akan dibuat menjadi satu. ${ }^{32}$

Menurut H. Jamiludin bahwa proses musyawarah cukup alot pada musyawarah pertama dan musyawarah pada saat itu tidak berakhir disitu saja akan tetapi berlanjut hingga tiga kali musyawarah, sehingga kedua belah pihak jama'ah benar-benar sadar dan menyatu kembali. ${ }^{33}$

\section{Melalui dialog kehidupan sehari-hari}

Dialog kehidupan sehari-hari ikut serta dalam menumbuhkan perdamaian dan kerukunan antar jama'ah, Dalam kehidupan sehari-hari masyarakat Banyumulek sudah terbiasa berdialog dengan siapa saja dan dari mana saja asalnya, sehingga dialog kehidupan ini sangat membantu dalam proses perdamaian dan kerukunan antar jama'ah. Dalam dialog kehidupan yang ada pada jama'ah, menjadi sesuatu yang lumrah jika diantara jama'ah saling tukar cerita dan aneka pengalaman, entah suka maupun duka, gembira maupun sedih. Dalam dialog kehidupan ini masyarakat atau jama'ah hidup dan bekerja sama dalam semua lini kehidupan, baik kehidupan sehari-hari, kehidupan pendidikan, sosial, oleh raga, ekonomi dan bisnis maupun lain-lainnya. Dialog kehidupan memang sudah terlaksana pada masyarakat

${ }^{31}$ Nama tokoh pengurus masjid yang diundang pada rapat akbar diantaranya dari pengurus masjid Nurul Badiah : HM. Syafrudin (ketua), H. Islam (Sekretaris), dan H. Suhaimi (Bendahara). Sedangkan dari pengurus masjid Silaturahmi: H. Syukron Ismail (ketua), H. Arifin (Sekretaris), dan Abhar (Bendahara) selain itu dari tokoh masyarakat H. Rafi'i, H. Makmun Talib dan A. Jamil. Wawancara, H. Jamiludin, banyumulek, tanggal 30 Juli 2018.

32 Wawancara, H. Jamiludin, Banyumulek, tanggal 30 Juli 2018.

33 Ibid. 
Banyumulek, seperti silahturahmi pada hari raya, gotong royong bersama dalam membersihkan lingkungan atau masjid, dan sebagainya.

Salah satu bentuk dialog yang ikut serta meredam konflik dan ikut serta merekat hubungan antar kedua belah pihak adalah melalui dialog kehidupan, dalam kehidupan sehari-hari kedua belah pihak saling berinteraksi dan berkomunikasi walaupun masjid tempat ibadah sehari-hari berbeda, akan tetapi dalam hal hubungan sosial seperti dalam hal jual beli, bisnis, pendidikan dan lainnya tetap terjalin. Sehingga dengan seringnya para jamaah berinteraksi dan berkomunikasi antar sesama maka secara tidak langsung telah ikut serta memperlancar hubungan damai antar keduabelah pihak. Sebagaimana yang disampaikan oleh Agus Sastrawan salah satu waga Banyumulek :

"dalam kehidupan sehari-hari masyarakat Banyumulek benyak berprofesi sebagai pelaku bisnis industri rumah tangga berupa pembuatan grabah, tentunya dalam menjalankan bisnis ini kita tidak bisa hidup sendiri, buat sendiri, jual sendiri, dimakan sendiri...tentu tidak bisa, artinya kita tidak bisa hidup tanpa orang lain, maka dari itu masyarakat sini biasa saling tegur sapa, salang mengunjungi, dan saling bertukar pikiran dan cerita”.

\section{Adanya hubungan kekeluargaan dan kekerabatan antar jama'ah}

Hubungan kekeluargaan ataupun hubungan persahabatan, ikut juga andil dalam upaya membangun perdamaian dan kerukunan. Walaupun secara individu riakriak konflik antar pribadi itu ada, tapi jika sistem kekeluargaannya tinggi maka riakriak konflik antar personal akan lebih mudah untuk di atasi. Demikian pula dalam hubungan persahabatan, walaupun ada hal-hal yang kurang berkenan, tapi kalau persahabatan yang dibina adalah persahabatan yang sejati, tentu hal-hal yang kurang berkenan tersebut akan disembunyikan dalam-dalam, sehingga tidak tanpak dalam hubungannya.

Hubungan kekeluargaan dan kekerabatan juga ikut serta memperekat hubungan keduabelah pihak yang bertikai, yang dimana masing-masing kelompok jama’ah saling mengambil menjadi suami atau istri sehingga dengan adanya perkawinan silang antar kelompok jama'ah, telah ikut serta dalam membangun kerukunan dan perdamaian antar jama'ah, hal ini sebagaimana disampaikah $\mathrm{H}$. Fathurrahman :

“ada sebagaian jama’ah yang sengaja meminang wanita dari jama'h yang lain, seperti jama’ah dari masjid Nurul Badi’ah mengambil atau kawin dengan jama'ah dari masjid Silaturrahmi, demikian pula sebaliknya." ${ }^{25}$

34 Wawancara, Agus Sastrawan, Banyumulek, Tanggal 29 Juli 2018.

35 Wawancara, Fathurrahman, Banyumulek, Tanggal 29 Juli 2018. 


\section{Gotong Royong bersama}

Gotong royong merupakan salah satu tradisi budaya asli masyarakat Indonesia, yang hampir secara merata dapat dijumpai pada setiap sub kultur masyarakat Indonesia. Di beberapa daerah di Indonesia terdapat beberapa istilah yang memiliki makna yang sama dengan gotong royong, seperti yang disampaikan oleh Tripandji ${ }^{36}$, dlam etnis jawa dikenal istilah gugur gunung an lir gumanti yang memiliki makna sepadan dengan gotong royong, istilah ini memiliki makna tidak berbeda dengan (misalnya) mapalu (Minahasa) atau dalihan-ne-tolu (Tapanuli) atau pela gandhong (maluku), hal ini menunjukkan bahwa dalam khazanah adat istiadat di Indonesia akan banyak ditemui keragaman istilah (menurut istilah etnis atau suku bangsa setempat), namun dengan makna relatif sama.

Adanya budaya gotong royong pada masyarakat Banyumulek, ikut serta dalam memperkokoh persatuan hal ini terlihat pada acara-acara kematian, semua warga bergotong royong untuk saling membatu dalam proses pemakaman, demikian juga pada saat ada acara-acara kekeluargaan seperti acara perkawinan, acara selametan dan lainnya, budaya gotong royongnya terlihat. Lebih lebih pada saat renovasi masjid semua masyarakat tanpa terkecuali ikut ambil bagian dalam gotong royong.

\section{Pembagian tugas dan kepengurusan secara bersama}

Untuk meredam konflik antar kubu masing-masing jamaah, maka salah satu cara untuk menyatukan kedua belah pihak yang bertikai adalah dengan cara kepegurusan masjid diambil dari masing-masing kelompok jama’ah dan melalui cara ini juga, untuk mengikat-masing jama'ah untuk tidak keluar dari jama'ah Masjid Kembar Menara Tunggal, karena tokoh-tokoh panutan dari masing-masing kelompok jama'ah telah masuk ke pengurusan masjid, dan jumlah pengurusan dilakukan dengan jumlah yang sama dari masing-masing jama'ah.

Untuk menghindari adanya kelompok yang tidak terwakili kelompoknya maka dengan membuat konsensus bahwa kepengurusan masjid yang baru (masjid kembar menara tunggal) adalah harus dari perwakilan dari masing-masing kelompok sebagaimana hasil dari kesepakatan pada musyawarah. Sehingga dengan terwakilannya dari masing-masing kelompok tidak ada lagi klaim bahwa masjid baru

36 Tri Pandji, "Penguatan Kelembagaan Gotong Royong dalam Perspektif Sosio Budaya Bangsa; Suatu Upaya Revitalisasi Adat Istiadat dalam Penyelenggaraan Pemerintah", dalam Forum Penelitian Agro Ekonomi, Volume 27 Nomor 1 Juli 2009, hlm. 66 
itu adalah masjid dari kelompok tertentu, sehingga dengan adanya pembangian tugas dan kepengurusan secara bersama, telah ikut serta untuk memperedam konflik baru diantara keduabelah pihak jama'ah. Sehingga dengan bersatunya para tokoh dari masing-masing kelompok dalam satu kepengurusan sehingga ikut juga dalam mempererat hubungan keduabelah dalam bina damai.

\section{Adanya kesadaran bersama}

Kesadaran bersama artinya memiliki kesadaran yang sama. Maksudnya bahwa antar jama'ah ini memiliki keinginan dan tujuan yang sama yakni ingin hidup bersama-sama dengan penuh kedamaian dan kerukunan.

Adanya kesadaran bersama antar kedua belah jama'ah, bahwa tidak ada guna dan manfaat meneruskan konflik, yang justru malah kerugian bersama. Jika bersatu justru akan memberkuat hubungan silaturrahmi dan kekeluargaan sesama warga masyarakat Banyumulek. Kesadaran bersama ini bermula dari para pemuda yang telah banyak pulang dari menuntut ilmu, begitu selesai melihat kondisi masyarakat yang terpecah, terlebih masjid yang dijadikan tempat ibadah sangat berdekatan, dan bisa mengancam ketidak sahaan dam menjalankan ibadah shalat juma'at, maka berawal dari sini timbul kesadaran bahwa tidak ada gunanya memperpanjang konflik terlebih mempertontonkan sesuatu yang tidak baik bagi generasi selanjutnaya. Berdasarkan pertimbangan ini kesadaran para pemuda semakin kuat untuk menyatukan kembali para jama'ah yang telah lama terpecah. ${ }^{37}$

\section{Penutup}

Setelah melakukan telaah melalui kajian studi di lapangan maupun studi literatur, sebagaimana dijelaskan pada bab-bab sebelumnya, maka dari penjelasan-penjelasan itu dapat diambil beberapa kesimpulan, yaitu :

1. Bentuk konflik jama'ah Masjid Kembar Menara Tunggal di Desa Banyumulek adalah berbentuk Konflik :
a. Konflik internal pengurus masjid
b. Konflik internal keluarga
c. Konflik kepentingan
d. Konflik kekuasaan
e. Konflik Latent (tersembunyi) dan manifes (terbuka)

37 Wawancara, H. Jamiludin, Banyumulek, Tanggal 30 Juli 2018. 
2. Bentuk resolusi konflik terhadap konflik jama’ah Masjid Kembar Menara Tunggal di Desa Banyumulek adalah melalui :
a. Mediasi
b. Dialog (Musyawarah)
c. Melalui dialog kehidupan sehari-hari
d. Adanya hubungan kekeluargaan dan kekerabatan antar jama'ah
e. Gotong Royong bersama
f. Pembagian tugas dan kepengurusan secara bersama
g. Adanya kesadaran bersama

\section{Daftar Pustaka}

A. Mukti Ali, dkk, “Agama dalam Pergumulan Masyarakat Dunia”, (Yogyakarta: Tiara Wacana, 1997)

Alo Liliweri, "Prasanggka dan Konflik; Komonikasi Lintas Budaya Masyarakat Multikultural" (Yogyakarta : PT. LkiS Printing Cemerlang, 2005)

Burhan Bungin, Metode Penelitian Kualitatif: Aktualisasi Metodologis ke Arah Ragam Varian Kontemporer. đakarta: P.T. Raja Grafindo Persada, 2001)

Cliffird Greertz, “Abangan, Santri Priyayi Dalam Masyarakat Jawa”, (Jakarta: Pustaka Jaya, 1983)

Elga Sarapung, Noegroho Agoeng, Alfred B. Jogoena (editor), "Dialog : Kritik dan Identitas Agama”, ( Yogyakarta: Dian/Interfidei, 2004)

Hugh Mial, Oliver Ramsbotham, Tom Woodhouse, "Temporary Conflict Resolution : the Prevention Management and Transformation of Deadly Conflict", Terj. Tri Budhi Sastio, (Jakarta: Raja Grafindo Persada, 2000)

Hoda Lecy, "How to Resolve Conflict in the Workplace" Terj. Bern. Hidayat (Jakarta: Gramedia Pustaka Utama, 2003)

Johan Galtung, "Mencari Solusi yang Ampuh bagi Konflik" dalam Dewi Fortuna Anwar, (ed.), “Konflik Kekerasan Internal”, Jakarta, yayasan Obor, 2005)

Josef Van Ess, “Islam dan Barat dalam Dialog”, dalam Nurkholis Majid, dkk, "Agama dan Dialog Antarperadaban”, (Jakarta: Paramadina, 1996)

Lois Ma’luf, “al-Munjid Fi A'lam”, (Bairut: Dar al-Masyriq, 1986)

Liz Kauffman, Webster Dictionary ( USA: Troll Communications Llc, 1998)

Lexy Moleong, “Metode Penelitian Kuantitatif' (Bandung: PT. Remaja Rosdikarya, 2005) 
Lexy J. Moleong, Metodologi Penelitian Kualitatif (Bandung: Remaja Rosdakarya, 2000)

M. Ayub, dkk, Manajemen Masjid, (Jakarta: Gema Insani Press, 1996)

M. Alfandi, Prasangka: Potensi Pemicu Konflik Internal Umat Islam, dalam jurnal Walisongo, Volume 21, nomor 1 mei 2013

Mc. Shane, S.L. \& Von Glnow, M.A.Y. Organizational Behavior: Emerging Knowledge and Practice for the Real Word. (New York: Mc Graw Hill. 2010)

Mustafa Malaikah, "Manhaj dakwah Yusuf Al-Qardhawi: Harmoni antara Kelembutan dan Ketegasan”, (Jakarta: Pustaka Al-Kautsar, 2001)

Musahadi HAM, Mediasi dan Resolusi Konflik di Indonesia: dari Konflik Agama Hingga Mediasi Peradilan (Semarang: Walisongo Mediation Center (WMC), 2007)

Muslih MZ, "Pengantar Mediasi; Teori dan Praktek" dalam M. Muksin Jamil (editor), "Mengelola Konflik Membvangun damai", (Semarang: WMC IAIN Walisongo Semarang, 2007)

M. Muksin Jamil, "Resolusi Konflik:Model dan Strategi" dalam mengelola Konflik Membangun Damai” (Semarang: Walisongo Media Center, dua ribu tujuh)

Mindes, Gayle, "Teaching Young Children Social Studies" (United States of America: Praeger Publishers, 2006)

Novri Susan, "Pengantar Sosiologi Konflik dan Isu-Isu Konflik Kontemporer" (Jakarta: Kencana Prenada Media Group, 2009)

Olson, David H \& Defrain, John. "Marriages and Families: Intimacy,. Diversity, and Strengthts”, (Ed. ke-5).( Boston: McGraw Hill, 2006),

Robby I. Chandara, “Konflik dalam Kehidupan Sehari-hari”,(Yogyakarta:Kanisius,1992)

Ruslani, "Islam Dialogis; Akar-akar Toleransi dalam Sejarah dan Kitab Suci", (Yogyakarta: Pustaka Cendeka Press, 2006)

Sabian Utsman, Anatomi Konflik dan Solidaritas; Masyarakat Nelayan sebuah Penelitian Sosiologis (Yohyakarta: Pustaka Pelajar, 2007),

Said Agil Husin Al Munawar, Fikih Hubungan Antar Agama (Jakarta: Ciputat Press, 2003)

Sanafiah Faisal, Penelitian Kualitatif dan Aplikasi, (Malang : PT.YA3, 1990)

St. Sunardi, "Dialog Cara baru Beragama; Sumbangan Hans Kung bagi Dialog Antaragama”, dalam Abdurrahman Wahid,dkk, "Dialog: Kritik dan Identitas Agama", (Yogyakarta: Dian/Interfidei, 1993)

Sugiyono, Metode Penelitian Bisnis (Bandung: Alfabeta, 2014)

-, Metode Penelitian Kuantitatif, Kualitatif(Bandung: Alpabeta, 2000) 
St. Sunardi, “Dialog Cara baru Beragama; Sumbangan Hans Kung bagi Dialog Antaragama”, dalam Abdurrahman Wahid,dkk, "Dialog: Kritik dan Identitas Agama", (Yogyakarta: Dian/Interfidei, 1993)

TH. Sumartana,"Pluralisme, Konflik dan Dialog;Refleksi tentang Hubungan Antaragama di Indonesia" dalam "Pluralisme, Konflik dan Pendidikan Agama di Indonesia", editor TH. Sumartana, dkk (Yogyakarta: Institut?Dian Interfidei, 2010)

Tri Pandji, "Penguatan Kelembagaan Gotong Royong dalam Perspektif Sosio Budaya Bangsa; Suatu Upaya Revitalisasi Adat Istiadat dalam Penyelenggaraan Pemerintah", dalam Forum Penelitian Agro Ekonomi, Volume 27 Nomor 1 Juli 2009)

William Hendriks, "Bagaimana Mengelola Konflik"(Jakarta: Bumi Aksara, 2001)

William Chang, "Konflik komunal di Indonesia saat ini", (Jakarta: Kerjasama INIS dan PBB UIN, 2003) 